\title{
Cost Reduction Technique in Photo Voltiac Cell
}

\author{
Swatantra Prakash Singh \\ Assoc Prof\& HOD EEE Department Aurora's Scientific and Technological institute Ghatkesar,RR Dist, \\ Hyderarbad (A P)
}

\begin{abstract}
Solar Photo Voltaic (PV) cell is a device which directly converts solar energy into electrical energy by means of photovoltaic effects. Photovoltaic cells are made of semi conductors which generate electricity when they absorb light. PV cells generate electricity by using the renewable energy technology which generates green power. The Photovoltaic industry in India is facing severe shortage of silicon, hence the Government of India is not able to achieve the set targets.

The purpose of this research paper is three fold:

1. To bring out the latest innovations to better the performance of PV modules.

2. Reduction of direct manufacturing cost.

3. Improve the conversion efficiency.

This paper bases its premise on mono crystalline silicon (mono Si), poly crystalline silicon (poly Si) and edge defined film fed which growth silicon (EFG-Si). It brings out the fact that economies of large scale production and effective raw material management hold the key to cost reduction of PV Cells and by the application of these silicon technologies we get very high efficient PV cells.
\end{abstract}

Key words: Renewable energy sources, Semi conductor, solar photo voltaic cell, Silicon, Mono Si, poly Si, $E F G-S i$, cost reduction, economies of large scale production.

\section{Introduction:}

Energy Security has become important for the economic development of the country. In the present day context it has become all the more imperative to conserve the nation's energy resources. The oil crisis of 1973 and concern for environment due to excessive use of fossil fuel have led to remarkable global effort in harnessing alternative renewable energy sources. The renewable energy sources such as the sun, wind, and biomass are also referred non conventional energy sources. Harnessing of energy through these resources using efficient technological advancements plays an important role in serving clean and green energy sources for mankind, most governments have substantial plan outlays directed towards encouraging this technology in order to exploit them commercially. The present paper is an effort to explore this technology in balance perspective. The economic growth of the nation, while conserving the nations non renewable resources is not sustainable until reliable energy is made available at a reasonable cost; conventional energy sources like coal, oil \& gas are becoming scarcer and costlier. They are not eco friendly and they are damaging environment by generating green house gases (GHG).Solar photovoltaic cell (SPVS) converts light radiation into electricity directly. It is eco friendly and green power. India is blessed with good resources as daily solar radiation level in most places; vary from 4 to $7 \mathrm{kwh} / \mathrm{m}^{2} /$ day average over the year.

Photovoltaic cell is generate green power but it has low efficiency with high cost of material. These issued needs to solve in near future. Shortage of silicon and old technology have adversely impact the cost of PV cell. By use of better material conversion efficiency will improve.

\section{PV Technologies:}

There are two PV technologies crystalline silicon pv and thin film pv.

Crystalline Silicon pv(c-si):- Crystalline silicon pv are made by slicing high purity silicon into pure silicon into pure wafers the thickness of a human hair.Three types of silicon crystalline silicons are used in the production of solar cells.

Mono crystalline silicon:-Mono crystalline silicon uses single crystal wafer cell cut from cylindrical.ingot.These cells are very expensive due to manufacturing process involved.

Polly crystalline silicon:-Polly crystalline silicon cell are made from square cast ingots.These cell are less expensive due to manufacturing process than mono-crytalline cells but less efficient.

Ribbon Silicon:- Ribbon silicon cells are made by drawing thin flat films from molten silicon creating a multi crystalline structure.Their efficiency are low but costs are cheaper. 
Thin Film PV(CdTe,A-Si,CIGS):-

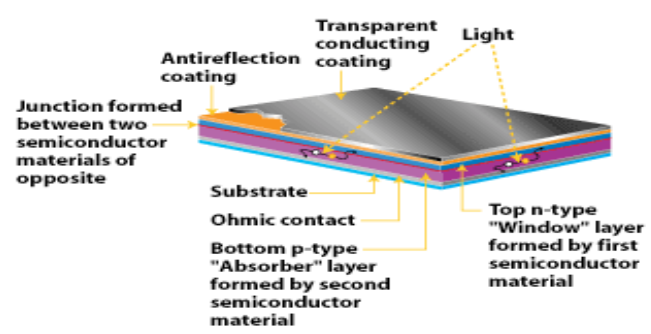

Thin film PV is fastest growing sector of the solar cell manufacturing industry.Thin film cells are manufactured by applying very thin layers of semi conductor material to inexpensive material such as glass,plastic or metal. Thin film semi conductor materials are absorb light very easily than c-Si. There are three leading manufacturing thin- film pv modules presently:- Cadmium Telluride(Cd Te):-

Cadmium telluride thin film currently has the lowest productoin cost \& higher efficiency (presently 6-11\% limited to $31 \%$ maximum).

Amorphous silicon(a-Si):- Amorphous silicon thin film uses a highly proven but slower deposition manufacturing process which result in lower effiency(Presently 6-8\% limited to $12 \%$ inlab.).

Copper Indium Gallium Selenide(CIGS):-Copper Indium Gallium Selenide has been able to reach to the highest efficiencies in production $13-14 \%$.

Cost reduction:-

Manufacturing of solar cells are already using innovative cost reduction and material saving technologies in term of usage of thinner wafer,thinner glass,beter/alternative material,optimized process and scaling up production.

Three mian factors such as economic scale production, conversion efficiency and optimized process hold the key to cost reduction.Various cost reduction issues and trends for crytalline thin film,amorphous silicon and micro crystalline technology used.

Crystalline Silicon Technology:-

Crystalline silicon technology solar cells cost can reduce by reduction of silicon usage and inprove the efficiency of cell.In order to reduce the usage of silicon, use thinner wafers, maximize the production and towards alternative routes to production of wafers such as ribbon growth on substrate silicon(RGSS) wafer and string ribbon.This will reduce the weight of cell,reduce the cost of energy generated and installation cost.

Thin film technology: Cost Reduction

To reduce the manufacturing cost of pv cell,increase the R\&D thrust and volume of production sales.Research and development(R\&D) can increase efficiencies at module level by increasing deposition rate of semiconductors and other materials.High volumes will give lesser cost of inventory items.Follwing important areas should highlight to reduction of cost:-

(a)Better testing\&measurement techniques.

(b)Module'active area of solar cell should increased.

(c)Deposition process of semiconductors\& other materials should optimized.

Amorphous-Silicon(a-Si) and Micro-Crytalline Silicon Cell:-

In this cell a-Si is used in top layer and micro crystalline silicon is used as the bottom layer to combine the advantages of both technologies. This is called hybrid module.

Hetrojunction with Intrinsic Thin layer(HIT)Cell:-

Global need of solar energy increasing rapidly.The world production volume of solar cell reach more than $2500 \mathrm{MW}$ per year.To full feel this Sanyo has decided to increase production capacity of HIT solar cell. HIT solar cell has high efficiency\& less generating cost. 


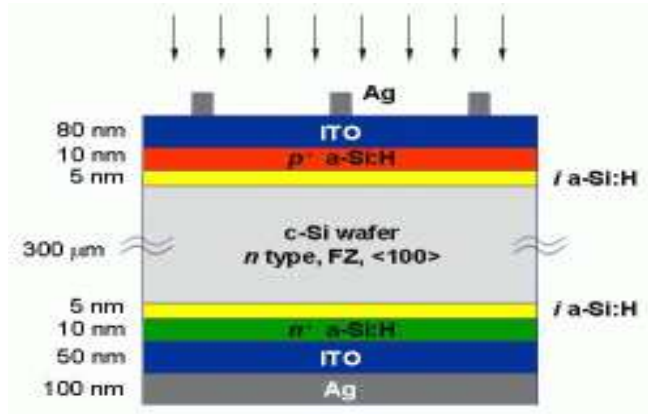

III. Conclusion:

The period of 1979 to 2012 is witnessed a historical cost reduction. More than ten fold silicon price reduce from USS 300 to uss 25 .Today manufactures are working on 150, 156 and200 mm cell size.Further reduction of wafer thickness also reduce cost of pv cell.Recycling of silicon waste will help cost reduction.PV cell price will go further in coming future combine effort of latest pv technologies.

\section{ACKNOWLEDGMENT:}

I would like express my profound sence of appreciation and gratude full team of publicing members for publicing of my PhD research paper.I am very greatful to my guide $\mathrm{Dr}$ A Prasad professor in mech dept JNT university Hyderabad for his precious suggestion\& moral support. Swatantra Prakash Singh

\section{References:}

[1] www.quantum msp.com/en/solar energy/ acomparision of pv technology www.nrel.gov

[2] Technology Road map solar pv energy, IEA Publications,9rue de la federation,75739 paris cedex, October 2010

[3] SESI JOURNAL 2007 Volume 17 Nos.1\&244 Cost Analysis of Solar Photovoltaics

[4] Pernick, R. and C. Wilder (2008), Utility Solar Assessment (USA) Study: Reaching Ten PercentSolar by2025, Clean Edge Inc. and Co-op America

[5] Philibert, C. (2011), Interactions of Policies for Renewable Energy and Climate, International Energy

[6] Agency, Paris. http://www.iea.org/publications/free_new_Desc.asp?PUBS_ID=23NY.

[7] Solar Junction (2011), Solar Junction Breaks World Record with 43.5\% Efficient CPV Production Cell,

[8] http://www.sj-solar.com/downloads/Solar_Junction_World 